The Open Agriculture Journal
Bentham open
Content list available at: www.benthamopen.com/TOASJ/
DOI: $10.2174 / 1874331501610010075$

REVIEW ARTICLE

\title{
Integration of Functional and Traditional Food in Emerging Markets: Regulatory and Substantive Aspects of Yerba Mate and Quinoa
}

\author{
Claudia Elena Gafare ${ }^{1}$, Mauro Serafini ${ }^{2}$, Giulia Lorenzoni ${ }^{*}, 3$ and Dario Gregori ${ }^{3}$ \\ ${ }^{I}$ Department of Nutrition, University of Buenos Aires and Food and Diet Therapy Service, Acute General Hospital Juan \\ A. Fernández, Buenos Aires, Argentina \\ ${ }^{2}$ Department of Environmental Biology, University of Roma "La Sapienza", Roma, Italy \\ ${ }^{3}$ Unit of Biostatistics, Epidemiology and Public Health, Department of Cardiac, Thoracic and Vascular Sciences, \\ University of Padova, Padova, Italy
}

\begin{abstract}
Given the rising cost of healthcare, the increase in life expectancy and the wish for a better quality of life, the request for foods and beverages producing a beneficial effect on health has increased worldwide. "Functional food" is a new concept and may play a key role in diseases' prevention and management. Although its meaning is currently under definition, its role in global health improvement is growing constantly.

This article aims at giving a description of existing legislation on functional food in South America, identifying future directions for health and marketing policies. Furthermore, authors provide a literature revision on two products widely consumed in Latin American countries: Yerba Mate and Quinoa. Thanks to their beneficial health effects in terms of disease prevention and promotion of well-being, they may be considered as functional foods with a potential key role in health care.
\end{abstract}

Keywords: Food Policies, Functional Food, Health Claims, Nutrition, Quinoa, Yerba Mate.

\section{INTRODUCTION}

Consumers' needs have changed considerably the field of food manufacturing. Given the rising costs of healthcare, the increase of life expectancy and the wish for a better quality of life, the request for foods and beverages producing a beneficial effect on health has increased worldwide [1]. This situation prompted research to identify and produce food with functions that can improve health and well-being, reducing (or delaying) the risk of major diseases related to nutrition $[2,3]$. In this scenario, the concept of functional food plays a key-role: functional foods are those foods which are normally part of a diet and that contain biologically active components able to determine an effect on human health [4]. The development of such concept represents an important market potentiality. Although functional food has been introduced in the market in recent years, it has reached rapidly a significant market share [5]. The market of functional food is spreading worldwide (about 7-10\% per year) [6]; this is an important value, since it represents a new economic opportunity, particularly for many developing markets. Estimates of the size of the functional food market vary widely from $\$ 11$ billion to $\$ 155$ billion annually- depending on the definition [7]. This because the concept of functional food does not have a common definition and it is usually confused with other product classes from nutraceutical and natural health settings [8]. "Functional food" is essentially a marketing term, and it is not recognized by law on a global basis [9]; this condition leads countries to develop their own legislation on functional foods. Adequate legislation is essential to maintain high standards in food safety and quality, and to improve health, thus the lack of a shared legislation is leading to differences, from country to country, in reporting health claims on food products [10]. Some countries have

\footnotetext{
* Address correspondence to this author at the Unit of Biostatistics, Epidemiology and Public Health, Department of Cardiac, Thoracic and Vascular sciences, University of Padova, Via Loredan 18, 35121, Padova, Italy; Tel: +39 3333654846; E-mail: giulia.lorenzoni@unipd.it
} 
developed a legislation on health claims (for example, the Health Canada Department in Canada, the Food and Drug Administration in the USA, the Ministry of Health, Labour, and Welfare in Japan, the Korean Food and Drug Administration (KFDA), the State Food and Drug Administration (SFDA) in China, and the Food Control Department in Singapore). Others have developed regulations both on health and nutrition claims (e.g. European Union, Australia and New Zealand) [10].

The present paper reviews the legislation on functional food in some countries of South America. Furthermore, this article looks at the future perspectives of this type of food in Latin America, providing information on two products widely consumed in Argentina: Yerba Mate and Quinoa.

\section{Legislation on Functional Food and Health Claims in Latin America}

The concept of functional food was first introduced in Japan in 1984 when the Japanese Ministry of Education promoted research in the field of food functionalities [11]. However, functional foods have a longtime history, or better yet a 'tradition of use' based on traditional knowledge [12]. Clearly, an adequate legislation on functional foods is essential to protect public health and stimulate technological development. In Latin American countries, an unified definition of functional foods and a shared regulation for functional foods/ingredients do not exist yet [13].

\section{Legislation Framework in Brazil}

Among the countries of South America, Brazil was the first one to develop legislation on functional food, in 1999. The regulation prohibited the use of therapeutic claims and permitted the adoption of claims on the reduction of generic disease risk and on the structure/function of certain foods [14]. Although in Brazil the concept of functional foods has not been defined, rules have been based on the idea that functional food is part of a normal diet (therefore not a drug) and may produce benefits beyond basic nutrition [13]. The Brazilian authority in charge of approving functional properties claims, bioactive substances, and isolated products is the National Health Surveillance Agency (ANVISA).

\section{Legislation Framework in Chile}

Chile has a regulation on food claims, which dates back to 2005. All food products must report in their labels the nutritional claim, as set forth by the Food Sanitation Regulation. All medical-type indications are forbidden. The Health Properties Claim must be recognized scientifically, or it must have been agreed globally, and must be part of the Technical Regulations on Nutritional Guidelines approved by the resolution of the Ministry of Health. According to Chile's regulation, neither the Health Properties in Food Claim nor the Nutritional Properties Claim of a certain food product can include false associations with health benefits. It is also forbidden to induce unnecessary consumption of a product, suggesting the idea of protection against illness [15]. The technical regulation of food claims on health properties reports a list of claims that must be used if a relation between a food product, nutrient or other substance and a health condition has been established. This list contains a definition of the association, the essential characteristics of food, and the required message framework. These associations are under constant revision by health authorities and may be modified depending on scientific progress [16].

\section{Legislation Framework in Argentina}

In Argentina the definition of Functional Food is analysed by an ad hoc team created in 2009 by the National Food Commission (CONAL, Comisión Nacional de Alimentos). CONAL is a technical institution with the aim to assess, support and monitor the National Food Control System (SNCA, Sistema Nacional de Control de Alimentos). Among CONAL's activities, there is the monitoring of SNCA members which must enforce Argentina's Food Code in Argentina's territory. Other groups belonging to CONAL made research in the field of probiotics and prebiotics, creating a protocol that establishes the necessary requirements and evaluations to include prebiotics or probiotics in specific food products. Such projects were incorporated to Argentina's Food Code towards the end of 2011 through the following regulations: Joint resolution SPRel 229/2011, and SAGyP 731/2011, and Joint Resolution SPRel 261/2011, and SAGyP 22/2011. Within this framework, any representation that expresses/suggests or implies the existence of a relationship between a food product (or a constituent of such food product) and health is considered as a "Health Property Claim”. Three different categories have been distinguished: 1. Nutrient Function Property Claim; 2. Other Function Property Claim OR Enhanced Function Property Claim; and 3. Health Risk Reduction Property Claim. Currently Argentina's Food Code prohibits overtly all indications on labels or notices, advertising on radio, or TV as well as written advertising which refer to medical [17] or therapeutic properties of a food product, or which advise its 
consumption on the basis of health reasons (Section 235 of Argentina's Food Code, adopted by Joint Resolution SPRyRS 149/05 and SAGPyA 683/05).

The implementation of this regulation with additional information, the wide variety of criteria adopted and other issues, such as the inclusion of these indications in a regulation framework, is an important matter, still under debate at CONAL [18].

\section{Functional and Traditional Food in Argentina: Yerba Mate and Quinoa}

Regarding the future perspectives of functional food products in Argentina, we report information on two functional food products that are widely consumed in the country: Yerba Mate and Quinoa.

\section{Yerba Mate}

"Mate" is the infusion prepared with Yerba Mate leaves (Ilex Paraguaiensis), a popular plant especially in Argentina, Brazil, Paraguay and Uruguay. The infusion of Yerba Mate seems to have several health benefits, including a digestive and purifying effect due to the large amount of water used for its consumption [19]. Based on the results of extensive research, Yerba Mate consumption appears to reduce LDL (low-density lipoprotein) cholesterol, stimulating the increase of HDL (high-density lipoprotein) cholesterol both in vitro and in vivo [20, 21], and to protect LDL cholesterol from oxidation, stimulating the activity of important antioxidant body enzymes. It has been shown that the consumption of extracts of Yerba Mate may contribute to increase antioxidant defense against free radicals. Yerba Mate has been reported to have high levels of xantines (which stimulate the central nervous system) and up to 12 powerful polyphenols, among which, chlorogenic acid and quercitin seem to have an anti-adipogenic effect, down-regulating the expression of genes involved in the adipogenesis [22]. The inhibitory effect on lipase activity and on obesity has been reported in obese mice treated with $1-2 \mathrm{~g} / \mathrm{kg}$ of Mate tea, after 8 weeks of high-fat diet. The results showed that Mate suppressed the increase of body weight, decreasing the serum triglycerides and LDL cholesterol concentrations, and the liver lipid content [23]. These findings suggest that Mate may be useful in the treatment of obesity caused by a high-fat diet.

In a study conducted on postmenopausal women by Conforti et al. [24], Yerba Mate consumption seems to be associated also with an high bone mineral density (BMD) at the lumbar spine and femoral neck, suggesting a potentially protective effect of this plant on bone mass of postmenopausal women involved in the study.

Beyond functional properties, also the nutritional content of Yerba Mate is notable. Potassium, magnesium, vitamins B1, B2, C, A, riboflavin, carotene, choline, pantothenic acid, inositol, and 15 types of amino acids [25] present in this plant may make Yerba Mate a good source of nutrients, representing a good alternative to coffee or tea.

\section{Quinoa}

Quinoa belongs to the Chenopodioideae family (together with spinach, Swiss chard, and beetroot), but it can be compared to cereals due to its chemical composition and the form in which it is normally consumed. Quinoa represents an excellent example of functional food that aims at lowering the risk of various diseases. Its beneficial effects are related to its nutritional composition: minerals, vitamins and fatty acids give an important contribution to human nutrition and physiology, particularly for what concern cell membranes' protection and brain neuronal functions.

Furthermore, quinoa is considered the only element among vegetables to contain all essential amino acids [26]. The content of linoleic acid is very high [27], giving quinoa an important role in the reduction of LDL cholesterol and in the increase of HDL. Several studies conducted on quinoa and other pseudocereals have suggested a hypocholesterolemic effect of its seeds, rich in fibers, saponins, and squalene. Particularly, the action of these substances appears to lead to the absorption of dietary cholesterol [28] and to the reduction of cholesterol synthesis in liver, suppressing the expression of HMG-CoA reductase, the enzyme involved in the mechanism of synthesis of cholesterol [28]. Additionally, Quinoa seems to have an antioxidant effect, which is related to the high quality of its oil, rich in essential fatty acids, like linoleate and linolenate, and to natural antioxidants like $\alpha$-tocopherol and $\gamma$-tocopherol [29]. Quinoa contains from 4.60 to $5.90 \mathrm{mg}$ of Vitamin E/100g. which prevents lipid peroxidation, thus contributing to keep the stability of the cell membrane structures, and to protect the nervous system, muscles and retina from oxidation.

The consumption of food rich in nutrients having health benefits on physiological processes is widespread worldwide, and the existence of natural functional compounds is important for medical research, which may take advantage of these substances for the control of physiological mechanisms in humans. 


\section{Functional Food: Future Perspectives}

Non-communicable diseases represent a dramatic public health burden in both developed and developing countries, killing more than 36 million people every year [30]. Development and implementation of primary prevention strategies (particularly those aiming at promoting healthy eating habits) are essential to deal with this situation. Functional foods may play an important role in this context.

Yerba Mate and Quinoa may represent two examples of functional foods given their potential benefits for human health. Yerba Mate appears to have several beneficial properties, in terms of antioxidant effect, aging prevention, cholesterol reduction, adipogenesis regulation, improvement of intellectual performance, and nutritional value. In addition, quinoa has been shown to have potential beneficial functional properties due to its nutrients, which bestow to quinoa several important functions, among which hypocholesterolemic and antioxidant activities.

Functional food products may represent an opportunity for both the food industry and consumers. However, further scientific research in the field of health effects of these products is crucial, concentrating not only on the biochemical properties of the substances contained in functional foods, but also on the frequency of their consumption, the potential interactions with other components in a diet, and the possible side effects, such as allergies and intolerance.

Governments play an essential role in the future of functional food. They may create a favorable environment for basic and applied research programs, promoting continuous and truthful consumer education on nutrition science, facilitating integration of public health topics, competitive and innovative economic development with ethical and ecological perspectives, and enforcing regulation systems for flexible and credible science-based claims on nutrition and health [31]. Furthermore, a clear regulatory system for manufacturing, sales, and advertising of functional foods is essential.

\section{CONCLUSION}

Functional food may represent a great opportunity to improve human health. Several food products, potentially considered functional food given their health benefits, are already used. Some examples of such foods are represented by Yerba Mate and Quinoa, which are widey consumed in South America. However, a unified regulation on functional food does not exist yet in Latin countries. The development of claims for already existing food products, as well as the development of new products and their own claims, is a scientific challenge and not only a marketing one. In order to optimize health on a global scale, it is crucial to find a unified definition for functional food, and to give health claims shared scientific criteria derived from methodologically sound scientific literature.

\section{CONFLICT OF INTEREST}

The authors confirm that this article content has no conflict of interest.

\section{ACKNOWLEDGEMENTS}

The work has been partially supported by an unrestricted grant of the Italian Ministry of Foreign Affairs and the Indian Ministry of Science \& Technology.

\section{REFERENCE}

[1] Diplock AT, Ashwell M. Scientific concepts of functional foods in Europe. Consensus document. Br J Nutr 1999; 81(Suppl. 1): S1-27. [http://dx.doi.org/10.1017/S0007114599000471] [PMID: 10999022]

[2] Arai S. Global view on functional foods: Asian perspectives. Br J Nutr 2002; 88(2)(Suppl. 2): S139-43. [http://dx.doi.org/10.1079/BJN2002678] [PMID: 12495455]

[3] Sharma D. Bioprospecting for drug, research and functional foods for the prevention of diseases-Role of flavonoids in drug development. J Sci Ind Res 2006; 65: 391-401.

[4] Ozen AE, Pons A, Tur JA. Worldwide consumption of functional foods: a systematic review. Nutr Rev 2012; 70(8): 472-81. [http://dx.doi.org/10.1111/j.1753-4887.2012.00492.x] [PMID: 22835140]

[5] Kotilainen L, Rajalahti R, Ragasa C, Pehu E. Health enhancing foods: Opportunities for strengthening the sector in developing countries. In: Agriculture and Rural Development Discussion Paper 30. 2006.

[6] Fitzpatrick K. Research Report Winnipeg. Manitoba: University of Manitoba 2003. 
[7] Weststrate JA, van Poppel G, Verschuren PM. Functional foods, trends and future. Br J Nutr 2002; 88(3)(Suppl. 2): S233-5. [http://dx.doi.org/10.1079/BJN2002688] [PMID: 12495465]

[8] Veeman M. Policy development for novel foods: issues and challenges for functional foods. Can J Agric Econ 2002; 50(4): 527-39. [http://dx.doi.org/10.1111/j.1744-7976.2002.tb00353.x]

[9] Henry CJ. Functional foods. Eur J Clin Nutr 2010; 64(7): 657-9. [http://dx.doi.org/10.1038/ejen.2010.101] [PMID: 20606685]

[10] Malla S, Hobbs JE, Sogah EK. Functional foods and natural health products regulations in Canada and around the world: nutrition labels and health claims. Report prepared for the Canadian Agricultural Innovation and Regulation Network (CAIRN) 2013.

[11] Yamada K, Sato-Mito N, Nagata J, Umegaki K. Health claim evidence requirements in Japan. J Nutr 2008; 138(6): $1192 \mathrm{~S}-8$. [PMID: 18492856]

[12] Arai S. Studies on functional foods in Japan-state of the art. Biosci Biotechnol Biochem 1996; 60(1): 9-15 [http://dx.doi.org/10.1271/bbb.60.9] [PMID: 8824819]

[13] Lajolo FM. Functional foods: Latin American perspectives. Br J Nutr 2002; 88(2)(Suppl. 2): S145-50 [http://dx.doi.org/10.1079/BJN2002679] [PMID: 12495456]

[14] Resolution no. 18, de 30 de abril de 1999. Aprova o RegulamentoTécnicoque estabeleceasdiretrizesbásicas para análise e comprovação de propriedadesfuncionais e ou de saúdealegadasemrotulagem de alimentos, constante do anexo desta portaria. DiárioOficial da União; PoderExecutivo, de 03 de maio de 1999.

[15] Decreto no. 977, de 13 de mayode 1997. Regolamento Sanitario del losAlimentos. Diario Oficial no. 35.764

[16] Decreto con Fuerza de Ley 1, de 23 de septiembre de 2005. Fija texto refundido, coordinado ysistematizado del Decreto Ley no. 2.763, de 1979 y de lasLeyes no. 18.933 y No. 18.469 .

[17] ResoluciónConjunta 149/2005 y 683/2005. Codigo Alimentario Argentino. Incorpóranse al mencionadoCódigolasResoluciones del GrupoMercadoComún No. 26/2003 "ReglamentoTécnicoMercosur para Rotulación de AlimentosEnvasados" y No. 46/2003 "ReglamentoTécnicoMercosursobreRotuladoNutricional de AlimentosEnvasados".

[18] ActasComisión Nacional de Alimentos (CONAL). Available from http://www.conal.gob.ar/default.php

[19] Bracesco N, Sánchez AG, Contreras V, Menini T, Gugliucci A. Los recientes avances en la investigación Ilex paraguariensis. Minireview. J Ethnopharmacol 2011; 136(3): 378-84. [http://dx.doi.org/10.1016/j.jep.2010.06.032] [PMID: 20599603]

[20] Gugliucci A, Stahl AJ. Low density lipoprotein oxidation is inhibited by extracts of Ilex paraguariensis. Biochem Mol Biol Int 1995; 35(1): 47-56. [PMID: 7735139]

[21] Gugliucci A. Antioxidant effects of Ilex paraguariensis: induction of decreased oxidability of human LDL in vivo. Biochem Biophys Res Commun 1996; 224(2): 338-44.

[http://dx.doi.org/10.1006/bbrc.1996.1030] [PMID: 8702392]

[22] Heck CI, de Mejia EG. Yerba Mate Tea (Ilex paraguariensis): a comprehensive review on chemistry, health implications, and technological considerations. J Food Sci 2007; 72(9): R138-51. [http://dx.doi.org/10.1111/j.1750-3841.2007.00535.x] [PMID: 18034743]

[23] Martins F, Noso TM, Porto VB, et al. Maté tea inhibits in vitro pancreatic lipase activity and has hypolipidemic effect on high-fat dietinduced obese mice. Obesity (Silver Spring) 2010; 18(1): 42-7. [http://dx.doi.org/10.1038/oby.2009.189] [PMID: 19543216]

[24] Conforti AS, Gallo ME, Saraví FD. Yerba Mate (Ilex paraguariensis) consumption is associated with higher bone mineral density in postmenopausal women. Bone 2012; 50(1): 9-13. [http://dx.doi.org/10.1016/j.bone.2011.08.029] [PMID: 21920487]

[25] Vera García R, Basualdo I, Peralta I, de Herebia M, Caballero S. Minerals content of Paraguayan yerba mate (Ilex paraguariensis, S.H.). Arch Latinoam Nutr 1997; 47(1): 77-80. [PMID: 9429648]

[26] Abugoch James LE. Quinoa (Chenopodium quinoa Willd.): composition, chemistry, nutritional, and functional properties. Adv Food Nutr Res 2009; 58: 1-31. [http://dx.doi.org/10.1016/S1043-4526(09)58001-1] [PMID: 19878856]

[27] Przybylskia R, Chauhanb G, Eskina NA. Characterization of quinoa (Chenopodium quinoa) lipids. Food Chem 1994; 51(2): 187-92. [http://dx.doi.org/10.1016/0308-8146(94)90255-0]

[28] Takao T, Watanabe N, Yuhara K, et al. Hypocholesterolemic effect of protein isolated from quinoa (Chenopodium quinoa Willd.) seeds. Food Sci Technol Res 2005; 11: 161-7. [http://dx.doi.org/10.3136/fstr.11.161]

[29] Bhargava A, Shukla S, Ohri D. Chenopodium quinoa- An Indian perspective. Ind Crops Prod 2006; 23: 73-87. [http://dx.doi.org/10.1016/j.indcrop.2005.04.002] 
[30] Noncommunicable diseases Fact sheet. WHO 2013. Available from: http:/www.who.int/mediacentre/factsheets/fs355/en/

[31] Hernández AG. Tratado de Nutrición (rústica). $2^{\text {nd }}$ ed. 2010.

(C) Gafare et al.; Licensee Bentham Open

This is an open access article licensed under the terms of the Creative Commons Attribution-Non-Commercial 4.0 International Public License (CC BY-NC 4.0) (https://creativecommons.org/licenses/by-nc/4.0/legalcode), which permits unrestricted, non-commercial use, distribution and reproduction in any medium, provided the work is properly cited. 